NBER WORKING PAPER SERIES

\title{
PROTECTING FINANCIAL STABILITY IN THE AFTERMATH OF WORLD WAR I: THE FEDERAL RESERVE BANK OF ATLANTA'S DISSENTING POLICY
}

\author{
Eugene N. White \\ Working Paper 21341 \\ http://www.nber.org/papers/w21341
NATIONAL BUREAU OF ECONOMIC RESEARCH
1050 Massachusetts Avenue
Cambridge, MA 02138
July 2015

The author would like to thank the participants in conferences and seminars at the Banque de France, the Federal Reserve Bank of Atlanta, and New York University. Special appreciation for many comments and suggestions goes to Michael D. Bordo, Gary Richardson, William Roberds, Hugh Rockoff, and David C. Wheelock. Financial support from the National Science Foundation under Grant No. 1127094, Rutgers University's ARESTY program and Rutgers' Research Council grants is gratefully acknowledged. The views expressed herein are those of the authors and do not necessarily reflect the views of the National Bureau of Economic Research

NBER working papers are circulated for discussion and comment purposes. They have not been peerreviewed or been subject to the review by the NBER Board of Directors that accompanies official NBER publications.

(C) 2015 by Eugene N. White. All rights reserved. Short sections of text, not to exceed two paragraphs, may be quoted without explicit permission provided that full credit, including $\odot$ notice, is given to the source. 
Protecting Financial Stability in the Aftermath of World War I: The Federal Reserve Bank of Atlanta's Dissenting Policy

Eugene N. White

NBER Working Paper No. 21341

July 2015

JEL No. E58,G01,N12,N22

\begin{abstract}
$\underline{\text { ABSTRACT }}$
During the 1920-1921 recession, the Federal Reserve Bank of Atlanta resisted the deflationary policy sanctioned by the Federal Reserve Board and pursued by other Reserve banks. By borrowing gold reserves from other Reserve banks, it facilitated a reallocation of liquidity to its district during the contraction. Viewing the collapse of the price of cotton, the dominant crop in the region, as a systemic shock to the Sixth District, the Atlanta Fed increased discounting and enabled capital infusions to aid its member banks. The Atlanta Fed believed that it had to limit bank failures to prevent a fire sale of cotton collateral that would precipitate a general panic. In this previously unknown episode, the Federal Reserve Board applied considerable pressure on the Atlanta Fed to adhere to its policy and follow a simple Bagehot-style rule. The Atlanta Fed was vindicated when the shock to cotton prices proved to be temporary, and the Board conceded that the Reserve Bank had intervened appropriately.
\end{abstract}

Eugene N. White

Department of Economics

Rutgers University

75 Hamilton Street

New Brunswick, NJ 08901-1248

and NBER

white@economics.rutgers.edu 
When inflation picked up speed after World War I, central banks responded by quickly raising interest rates, leading to the severe recession of 1920-1921. The Federal Reserve Bank of Atlanta (FRBA) could not offset the national deflationary policy, but it carried out an important lender-of-last-resort (LOLR) function, as described by recent theoretical advances (Freixas and Parigi, 2014). There would have been no need for the Atlanta Fed's intervention, if the interbank market for funds had worked perfectly to enable banks in all the Federal Reserve districts to manage their differing demands for liquidity, attributable to the regionally uneven recessionary shock (Allen and Gale, 2000; Freixas, Parigi and Rochet, 2000). ${ }^{1} \quad$ The intense shock to Atlanta's Sixth District, arising from its dependence on cotton and agricultural commodities, imposed a sharper contraction and a higher demand for liquidity from its banks. As the commodity-collateralized assets on their balance sheets were opaque to other banks, especially those outside of the region, troubled banks found it difficult to access the interbank market for liquidity because of the information asymmetry. Finding themselves illiquid, Sixth District banks refused to renew loans, forcing producers and factors to dump their stocks on the market. This situation presented the possibility of a "fire sale" where cotton and cotton bills might sell below their fundamental prices leading to a cascade of bank failures and a panic (Shleifer and Vishy, 1992; Diamond and Rajan, 2009; Caballero and Simsek, 2009). ${ }^{2}$ To prevent a fire sale, the FRBA, informed by bank examinations and by its discounting history with each bank, used its discretion to provide liquidity and assist with capital injections.

To carry out this policy the FRBA needed to borrow gold reserves from Federal Reserve banks that had surplus reserves. By borrowing heavily from other Reserve banks, the FRBA acted where the interbank market did not, to reallocate liquidity, even as the money stock contracted. $^{3}$ If the commodity shock had been permanent, sweeping bank liquidations would have eventually been required; but the recovery of cotton prices proved it to be a temporary shock, where the FRBA-enabled reallocation of liquidity was consequently temporary. The

\footnotetext{
${ }^{1}$ Allen and Gale (2000) and Freixas, Parigi and Rochet (2000) have modelled multi-region economies with systemic risk where the interbank market provides liquidity short regions with funds from excess liquidity regions. A shortage of aggregate liquidity can transmit a shock from one region to another, forcing unexpected liquidation of long-term contracts and potentially creating a general crisis.

${ }^{2}$ See Shleifer and Vishny (2011) for a survey of the literature on fire sales.

${ }^{3}$ The similarities between the gold settlement fund's facilitation of inter-Reserve bank borrowing and the recent Eurozone crisis where semi-autonomous financial systems are linked together by a common currency and face profound imbalances are examined in Eichengreen et.al. (2014).
} 
Atlanta Fed was not worried about moral hazard because it believed that the brutal recession was an extraordinary, not-to-be repeated event that was understood by its member banks ${ }^{4}$. While the Federal Reserve Board opposed the Atlanta Fed's efforts, it later relented and publicly admitted that the FRBA had acted appropriately as a LOLR. Its success may have emboldened the FRBA to be more expansionary than other Federal Reserve banks during the 1929 Florida panic and Great Depression, without incurring the wrath of the Federal Reserve Board that in 1920-1921 had pressed the Atlanta Fed to adhere more closely to rules as specified by the Board.

This episode shines a light on the pre-depression history of the Federal Reserve, which has been generally treated as a period when the Fed did not act as a LOLR. The Federal Reserve Act of 1913 did not contain any instructions on how the new central bank should act as a LOLR. Some of the founding fathers of the Fed, like H. Parker Willis and Carter Glass believed that if the Fed put the real bills doctrine into effect, there would be no panics in the future. Others like Paul Warburg saw that there was a clear need for the new central bank to be prepared to act in accordance with Bagehot's (1873) ${ }^{5}$ dictates. Bordo and Wheelock (2013) argue that the Federal Reserve Act impeded the Fed's ability to act as a LOLR by limiting its lending capacity, creating a decentralized governance structure, and restricting its membership. These constraints on the LOLR function appear to have been confirmed by historical accounts of the Fed that, for the most part, center on decision-making by the Federal Reserve Board. Its first real LOLR challenge is typically seen as occurring during the four banking panics of 1930-1933 (Friedman and Schwartz, 1963). However, before the New Deal reform of the Fed, much of policy was conducted by the twelve, semi-autonomous Reserve banks, each of whom had individual responsibility for maintaining gold reserves above the minimum reserve ratios, supervising member banks, and setting discount rates with the approval of the Federal Reserve Board. Consequently, there was a diversity of LOLR experience, and a full history requires an inclusion of the Federal Reserve banks' actions as lenders-of-last-resort. Differences in policies during the Great Depression between Federal Reserve banks have enabled Richardson and Troost (2009) to examine a quasi-experiment that revealed the effectiveness of an easier liquidity policy,

\footnotetext{
4 Hautcoeur, Riva and White (2014) and Mishkin and White (2014) have found that even during the classical gold standard era and in the early twentieth century, central banks exercised discretion to intervene when faced with the collapse of what would be termed today SIFIs (systemically important financial institutions) while injecting liquidity into the financial system as a whole. When successful, these interventions were accompanied by strong actions to limit moral hazard.

5 Surveying the Bank of England's responses to financial crises, Bagehot (1873) recommended that a central bank should lend freely at a high rate against good collateral to supply liquidity.
} 
comparing the FRBA and the Federal Reserve Bank of St Louis. In the last local crisis before the depression, Carlson, Mitchener and Richardson (2010) find that the Atlanta Fed's "bold, transparent, and targeted liquidity support" altered depositor expectations and halted a panic in Florida in 1929, limiting the number of bank failures.

This study is informed by primarily by the minutes of the FRBA's Board of Directors and its Executive Committee, preserved in the archives of the Atlanta Fed. These are vital records for understanding how policy was conducted in the Federal Reserve System before the New Deal concentrated more authority in the Board of Governors (Meltzer, 2003). The FRBA's Board and the Executive Committee formulated and were deeply involved in the implementation and execution of policy; their minutes thus constitute a detailed record of the Reserve bank's management. Unfortunately, while the activities of all the regional Fed's merit inclusion in a study of this period, this paper is limited to the Atlanta Fed because the archives of the other Reserve banks are not yet fully open.

In the first section of this paper the recessionary shock of 1920-1921 is described. Next, the conduct of policy by the Federal Reserve Board is examined, followed by how policy developed at the Federal Reserve Bank of Atlanta from its inception to 1920. The difficult years of 1920-1921 and the previously unstudied acrimonious debate between the Board and the Atlanta Fed is detailed in the fourth section. The final section concludes with how the Board came to terms with the dissenting policy of the Atlanta Fed.

\section{An Unparalleled Series of Shocks, 1918-1921}

Key dimensions of the shocks delivered to the American financial system by the termination of the First World War can be seen in Figure 1, which displays the rate of inflation on the right-hand vertical axis and the number of national and state bank failures on the left-hand axis from 1866 to $1929 .^{6}$ After the Civil War (1861-1864), the U.S. experienced a mild secular deflation until the 1890s when gold discoveries resulted in a mild secular inflation, with prices fluctuating around these trends (Friedman and Schwartz, 1963). Over the short-run of a few years, under the gold standard regime, there was typically no persistent inflation or deflation. In contrast to Europe, the U.S. had no central bank in this era to smooth adjustment to shocks or to

\footnotetext{
${ }^{6}$ There is no equivalent series for state-chartered bank failures for this whole period (White, 2013).
} 
manage financial crises, as the Second Bank of the United States had lost its charter in 1836. The only federal banking or monetary agency was the Office of the Comptroller of the Currency (OCC), created by the National Bank Act of 1864, which also established a national and uniformly regulated banking system, with what were then considered strict rules. Until the revival of state-chartered banking in the 1890s, federally chartered national banks were the dominant financial institution. Supervised by the OCC, national banks had relatively low failure rates, as seen in Figure 1, although there were some spikes in the bad years of the 1890s. When banks were examined by the OCC, their assets were marked to market and promptly closed when found to be insolvent. State banks were more weakly regulated and tended to be smaller and more rural, with higher failures rates, but their failures followed the same pattern as national banks (White, 2013).

Figure 1

Inflation and Bank Failures, 1866-1929

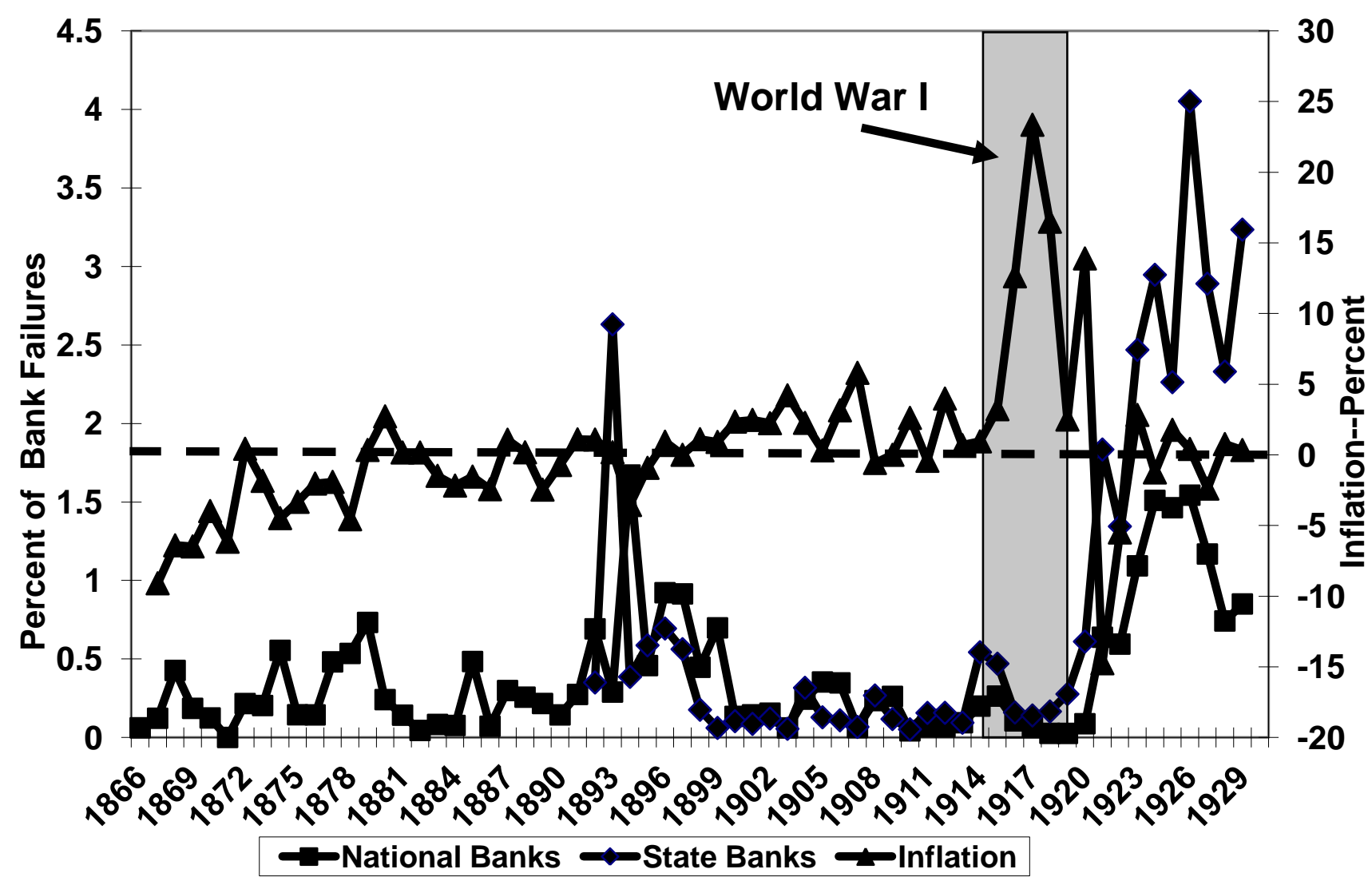

Source: White (2013). 
The OCC had no means to assist troubled banks and did not attempt to do so; its head office was provided with a limited budget by Congress that paid for little more than salaries, while the OCC's examiners were compensated by fees from the examined national banks. Regulations, notably double liability, created incentives that, coupled with supervision, left very small aggregate losses in the period 1865-1913 from national bank failures, approximately $\$ 44$ million, or \$1 billion in 2013 dollars and less than 1 percent of GDP for any year (White, 2013). In the absence of a central bank, the only assistance available to troubled banks came from the privately organized clearing houses, located in major cities, whose member banks might act collectively to provide temporary funds if they believed a bank to be inherently insolvent and a threat to financial stability (Friedman and Schwartz, 1963; Moen and Tallman, 1992)

Inflation during World War I and the postwar boom, where the price level nearly doubled, was followed by the sharp deflation of 1920-1922, when prices fell 22 percent. This experience was largely unanticipated. While there had been a major inflation during the Civil War, the postwar deflation that enabled the country to return to the gold standard was gradual, lasting from 1865 to 1879 . Financial institutions were not subjected to a giant shock, as occurred after World War I, and there was no upsurge in bank failures. For the fifty year period preceding 1914, there were only 501 national bank insolvencies. In contrast, bank failures rose to new heights in the 1920s, with 766 national bank and 4,645 state bank failures. Losses to national bank depositors for 1920s were higher than for the whole of the period 1865-1913, totaling $\$ 565$ million or nearly 1 percent of 1925 GDP (Calomiris and White, 1994). Figure 1 displays the national picture, but bank failures were concentrated in agricultural regions where commodity prices plummeted suddenly. During the war, there had been a major expansion of agricultural production, fulfilling demand for war commodities, such as cotton and replacing European production of foodstuffs such as wheat. Acreage had expanded and farmers had taken out mortgages and loans for inputs to expand output. When prices fell, farmers and their suppliers failed to make payments on their loans. Non-performing assets for rural banks increased quickly, threatening local financial systems.

The Sixth Federal Reserve district was dominated by cotton production. The movement of cotton prices is depicted in Figure 2. After fluctuating for decades between 5 and 15 cents a pound, the price of cotton soared to over 30 cents in 1917. In the brief, immediate postwar recession, the price in New York hovered around 33 to 35 cents a pound in August-September 1918, falling to 28 to 29 cents in March-April 1919, a modest drop. This national recession was 
quickly reversed by a vigorous expansion characterized by inventory accumulation and commodity speculation. The boom was reflected in the price of cotton that moved to a monthly peak of 42 cents a pound in April 1920. As the general price level had only increased 109 percent from 1913 to 1920 (Measuring Worth, 2014), the real price of cotton had effectively doubled. Yet, by 1921, cotton prices plunged below 12 cents or a 70 percent drop, while the Consumer Price Index, declined only 16 percent, implying a huge decline in real terms and a big swing in the terms of trade between the agricultural and manufacturing sectors. Although the American economy may have bounced back fairly quickly in 1921-1922, the cotton economy did not. Prices did not exceed 23 cents a pound until late 1922, and they did not recover to the 33 to 35 cents range of 1918 until the end of 1923.

Figure 2

\section{Monthly Wholesale New York Cotton Prices}

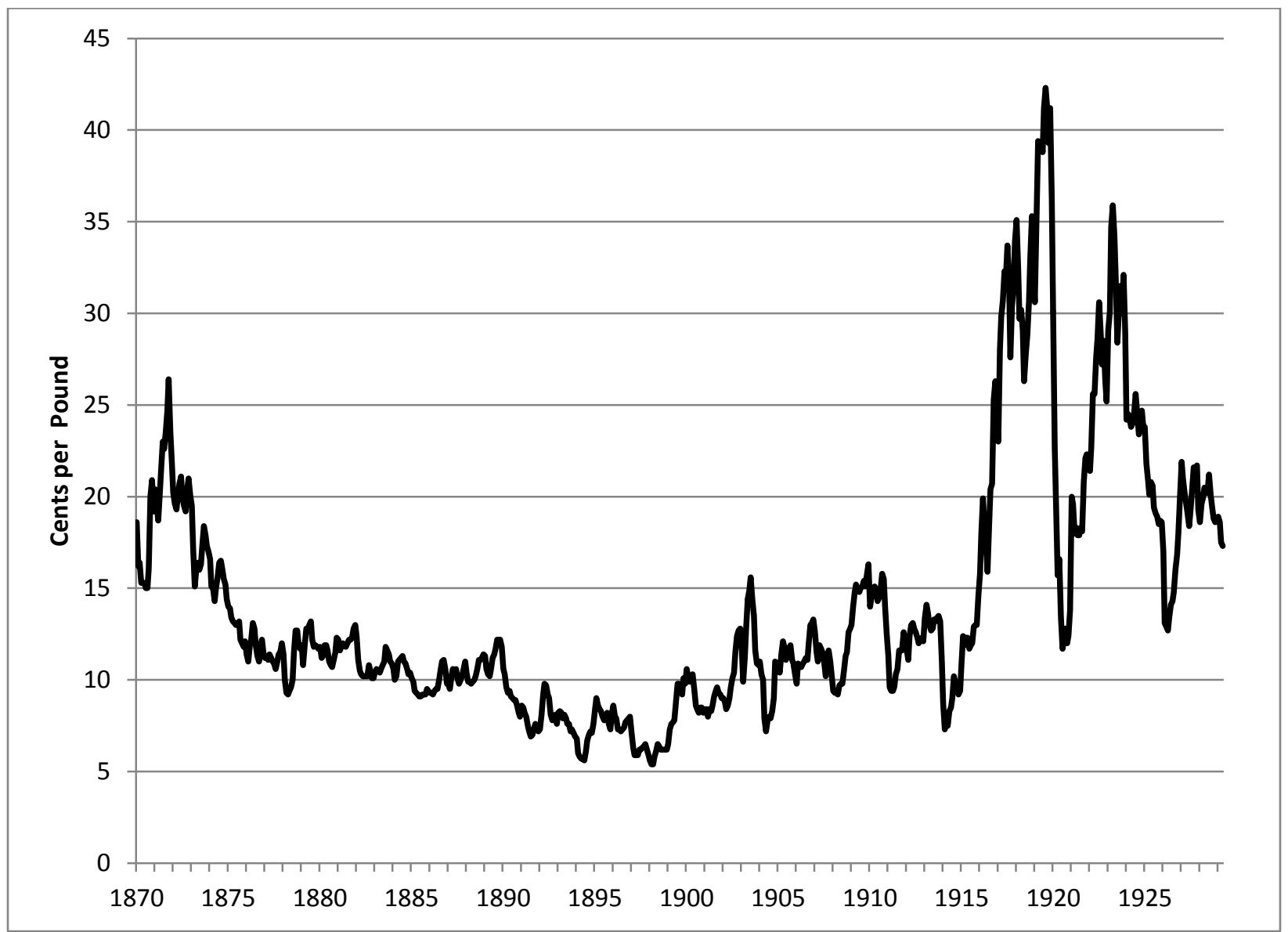

Source: NBER (2008).

To make matters worse, the cotton crop reached a historic high in 1921. The Atlanta Fed estimated that there were inventories of 4 million bales of low grade cotton. Not only did the 
price of cotton fall but so did the prices of rice, sugar, peanuts, naval stores, and livestock. Merchants and general stores who had made collateralized loans for supplies could not collect, leaving them unable to repay wholesalers, jobbers and manufacturers for goods they had bought on credit (Federal Reserve Bank of Atlanta, Annual Report, 1920). The precipitous decline in the price of cotton wreaked havoc on banks' balance sheets in the Atlanta district. Many loans were collateralized by cotton or assets tied to cotton production. If borrowers were unable to repay a loan, sale of the collateral could cause large losses on banks' capital accounts. Worse yet, any generalized effort to realize collateral could produce a fire sale, harming banks further. This assessment matches Shleifer and Vishny's (2010) summary of the threat that fire sales pose to financial stability, where a shock to the value of bank assets or their common underlying collateral can produce a cascade of declining asset prices, shrinking bank net worth, falling financial intermediation, and failing businesses.

The position of banks in the Sixth District was thus acute. Compounding the problem was that while all national banks had been required to become members of their respective Federal Reserve banks, it was optional for state-chartered banks. In spite of considerable efforts by the Atlanta Fed and the other Federal Reserve banks, few became member banks. If they were not member banks, they could not borrow from the Atlanta Fed's discount window. However, they could borrow from member banks; typically small-town rural banks borrowed from their larger city banks that were members. This extensive interbank borrowing linked the fate of all banks. The whole system, even those institutions not directly lending to cotton producers and the cotton industry, was thus endangered by the collapse of the price of cotton.

\section{Policy Making at the Center---the View from the Federal Reserve Board}

The asymmetric character of the shocks that hit the American economy after World War I produced a struggle between the regional Reserve banks and over how much policy decisionmaking should be centralized at the Federal Reserve Board in Washington D.C. Those shocks were aggravated by the Fed, when at the war's end, as the Fed sought to regain independence from the Treasury, it committed "several mistakes, some avoidable, some unavoidable in the circumstances." (Meltzer, 2003, p. 90)

Immediately after the cessation of hostilities in 1918, economic activity in the U.S. slowed, as orders for munitions were terminated and there was considerable uncertainly in the 
general economic outlook. Friedman and Schwartz (1963) characterized the contraction from August 1918 to March 1919 as sharp but brief and followed by an intense boom that peaked in January 1920. Contributing to this expansion was the low interest rate policy of the Fed, still obliged to assist the Treasury with bond sales. The rate for discounts and advances on eligible paper at the Federal Reserve Bank of New York had been set at 4 percent in April 1918, well below market rates. This New York rate remained that that level until November 1919, and none of the other eleven Reserve Banks posted a rate of more than $4 \frac{1}{2}$ percent. At these attractive rates, member banks discounted heavily, contributing to a monetary expansion and inflation. Measured by the GDP deflator, inflation rose from 4.3 percent in the first quarter of 1919 to 15.8 percent during the last two quarters of the year (Meltzer, 2003). Real rates were negligible if not negative.

This expansionary policy was driven, in part, by the U.S. Treasury's pressure to prevent a decline in the price of government bonds because of the feared consequences for commercial banks that had amassed huge holdings of war bonds and the final Victory bond issue (Friedman and Schwartz, 1963). It was, however, an unsustainable policy, given the Federal Reserve System's gold reserve requirements. The gold reserve ratio for the whole system that had been as high as 50.6 percent, in June 1919, quickly fell to 42.7 percent in January 1920, just above the 40 percent minimum. After a long battle within the Federal Reserve Board, the New York Fed was permitted to raise its rates to 4 3/4 percent in December 1919 and most banks followed suit. ${ }^{7}$ To this modest increase in discount rates, Congress passed the Phelan Act of 1920, granting the Fed the power to impose progressively higher discount rates on member banks that were heavy borrowers. When no agreement could be reached on how to implement this power, the Fed conceded it to the individual Federal Reserve banks (Meltzer, 2003, p. 105). As the commodity boom progressed, member banks in agricultural districts were undeterred by discount rates of 5 or 6 percent, as they often lent above 10 percent. The Atlanta, Dallas, Kansas City and St. Louis Reserve banks then took the lead and implemented progressive rates to deter these borrowers. Yet, this uneven policy did not deter member bank borrowing. Belatedly, in late January 1920

\footnotetext{
${ }^{7}$ When the Federal Reserve banks of New York and Boston voted to further increase their discount rates, the move was rejected by the Board. When the head of the New York Fed, Benjamin Strong insisted that the banks had the right to regulate their discount rates, the Secretary of the Treasury, Carter Glass threatened to remove him from office and obtained an opinion from the attorney general that gave the Board veto power over discount rate changes voted by the District banks. This significant victory ensured that only modest deviations in discount rates would be tolerated by the Board (Meltzer, 2003).
} 
the Fed permitted a number of Reserve banks to jack up their discount rates to 6 percent, which became uniform across all banks the following month.

As business cycle had just turned downward in January 1920, this action was probably excessive and Friedman and Schwartz comment "The rise in the discount rates in January was not only too late but also probably too much." (1963, p.231), turning a mild recession into a dramatic one. Yet, this interest rate hike seemed to have little immediate effect, as member banks did not cut back; and their borrowings at the Fed were higher than their reserve balances. Consequently the New York Fed raised its rediscount rate to 7 percent on June 1, 1920, quickly followed by Boston, Chicago, and Minneapolis, and lastly by Atlanta on November 1, 1920, with the remaining Federal Reserve banks keeping their basic rate at 6 percent.

Through the summer and into the fall of 1920, the Fed came under political pressure to reduce discount rates; and in autumn, the Board was urged to rescind a ruling made the year before that sharply limited the discounting of notes of cotton factors. By the end of 1920, Congress increased pressure on the Fed to cut rates, with a bill being introduced in the Senate to cap discount rates at 5 percent; and Senator Robert L. Owen, former Chairman of the Senate Banking Committee wrote two letters to the Board protesting the "Board's alleged policy of indiscriminate deflation and the refusal of credit to legitimate industries." (Harding, 1925, p. 197). The governor (chairman) of the Federal Reserve Board, William P.G. Harding's answer to these challenges was to argue that the authority and initiative for discount rate changes lay with the Federal Reserve banks, never mentioning the pressure that he and other officials placed on Atlanta for failing to conform to what they viewed as system-wide policy.

Responding to the increased discount rates in the second half of 1920 , member banks reduced their borrowings from the Federal Reserve banks, which meant, in turn, that the banks refused to renew loans to their customers. Friedman and Schwartz (1963) point out that it was easier to liquidate loans in the East than in agricultural regions where customers found it increasingly difficult to repay their loans. Many farmers did not survive the drop in agricultural prices and many rural banks went under. From 63 in 1919, bank insolvencies climbed to 155 in 1920 and 506 in 1921. Unemployment jumped from 4 percent in 1920 to 12 percent in 1921 and industrial and agricultural production fell 23 and 14 percent respectively, with wholesale prices tumbling 37 percent (Meltzer, 2003). But, there was not an immediate cut in the Fed's interest rates. Concerned about their ability to exercise control, many Fed officials were opposed to lowering discount rates, as market rates were higher (Meltzer, 2003). 
Benjamin Strong, Governor of the New York Federal Reserve Bank, was adamantly opposed to any decrease because the discount rates were not yet serving as penalty rates. He wanted to see member borrowing from the Reserve banks drastically reduced because it had fallen only 4 percent, and he believed that a 20 percent decline was needed. Like many Fed officials, he thought that a larger deflation was necessary to stabilize the economy and that any reduction in discount rates would ignite inflation. In his view, the Fed had to follow "Bagehot's gold rule" (quoted in Chandler, 1958, pp. 173-174.) and lend only at above market rates. Popular opposition to this policy, especially in agricultural states, stirred up criticism in Congress. In response, Congress revived the War Loan Corporation in January 1921 to finance agricultural and other exports, considered setting limits on discount rates, and opened a Joint Commission of Agricultural Inquiry to investigate the Fed's role in agriculture's economic distress (Meltzer, 2003).

Pressure mounted on the Fed to cut rates, but even when the Secretary of the Treasury, Andrew Mellon met with the Board in April 1921 and recommended a reduction to 6 percent, he was met with opposition. As late as the Governors' Conference of April 12, 1921, only the Governors of the Boston and Atlanta Federal Reserve banks favored a decrease to 6 percent, which was conceded to them three days later. Finally, the discount rate was lowered in New York to $6 \frac{1}{2} 2$ percent in May 1921 (Friedman and Schwartz, 1963). Rates cuts for all banks began in July----which was the month that the bottom of the recession was reached (Board of Governors, 1943; NBER www.nber.org Business Cycle Dates). In following months, industrial production recovered quickly though agricultural output remained sluggish, so that real GDP did begin to grow until the second quarter of 1922. Deflation and high interest rates prompted large gold inflows; and by October 1921, the New York Fed's gold reserve ratio reached 82 percent, leading to a new round of interest rate cuts, with the New York rate returning to 4 percent on June 23, 1922. Policy was thus restrictive in the recovery with high real rates in a deflationary environment, yielding declining system-wide discounts and advances until September 1922.

\section{Policy Making at the Regional Level}

As organizations, owned by their members who provided their capital by stock subscriptions and governed by member-elected boards of directors, the Federal Reserve banks were not government agencies, even though they had been created by an act of Congress. In 
conception, they owed much to the numerous private city clearing houses that assisted with the clearing and collection of checks, and which in times of crisis, had given assistance to members in need of liquidity, sometimes even rescuing members near collapse. Their usefulness was recognized when the government sponsored similar organizations that could provide temporary liquidity under the Aldrich-Vreeland Act of 1908, passed after the Panic of 1907. The twelve Federal Reserve banks were similar in conception to the clearing houses and Aldrich-Vreeland associations. They were to assist their members with the clearing and collection of checks, provide short-term loans and exercise some supervisions.

In terms of lending authority, the Federal Reserve Act of 1913 carefully specified the powers of the Federal Reserve banks (Section 14, Federal Reserve Act, 1915). They were permitted to "discount notes, drafts, and bills of exchange arising out of actual commercial transactions" "for agricultural, industrial or commercial purposes" but were forbidden to discount such instruments for carrying "stocks, bonds or other investment securities" except U.S. government securities. The maturity of discounts was limited to 90 days, except for those for agriculture or livestock, or bills of exchange for imports and exports where a maturity of six months was allowed. The Federal Reserve banks were also permitted to discount acceptances for imports and exports with maturities up to three months (Section 13, Federal Reserve Act, 1915). In addition to these discounts, the Federal Reserve banks could engage in open market operations, directly purchasing or selling any of the listed financial instruments.

Each Federal Reserve bank had limited monetary authority, being able to change its discount rates, subject to approval of the Federal Reserve Board. While the Board exercised this authority, it did not impose uniform rates; and there was divergence of up to 1 percent among banks in the System's first decade (Board of Governors, 1943, Table 115). In addition, Reserve banks had some discretion over the quality though not the type of collateral that could be discounted. Each bank was also required to maintain in gold and lawful money a reserve of 35 percent against its deposits and reserve of 40 percent against its Federal Reserve notes in circulation. Gold could be held in each bank's vaults or by certificates for gold at the Treasury. The reserve ratios thus had the potential to constrain the expansionary activities of individual Reserve banks. If either ratio fell below the required minimum, a Federal Reserve bank would be forced to reduce its lending. However, a deficit Reserve bank could request that a surplus Reserve bank rediscount bills that it had discounted for member banks in exchange for gold. The rediscounting Reserve bank then wired the "Gold Settlement Fund" in Washington, D.C., which 
transferred gold certificates between the accounts of the two banks, after which their reserve ratios were adjusted, raising the ratio for the borrowing bank and lowering it for the lending bank (Eichengreen, et.al. 2014). If Reserve banks were unwilling to provide assistance, the Federal Reserve Act empowered the Board to compel assistance at a rate that it fixed.

Unlike the financially constrained OCC, the Federal Reserve banks had substantial financial resources that had been accumulated during World War I, when they were induced to buy bonds for their own account and to lend to the public to purchase them to assist the massive financing needs of the federal government. As their balance sheets swelled, so did Federal Reserve banks' earnings. In 1916, the earnings of the FRBA were a mere $\$ 141,774$, but by 1918 , they stood at $\$ 1,758,000$ (Gamble, 1989). While they paid dividends to their member banks from this income, the Federal Reserve banks increased their surplus and their capacity to aid troubled member banks.

Officially, direct intervention in the affairs of a member bank was not countenanced by the Federal Reserve Act, and Federal Reserve banks were limited to the acquisition of information. Under the 1913 Act, the Comptroller of the Currency continued to conduct twice yearly examinations of national banks, and the state banking authorities examined state-chartered banks; but the Federal Reserve banks were given authority to conduct special examinations of both national and state member banks within their districts "to inform the Federal Reserve bank of the condition of its member banks and of the lines of credit which are being extended by them." (Section 21, Federal Reserve Act, 1915).

While this legal framework would seem to have kept interactions of the Federal Reserve Banks with their member banks at arms' length, some Federal Reserve banks took a much broader view of their role from the very beginning. A history of the Atlanta Fed (Gamble, 1989) described the intentions of the new Federal Reserve Bank of Atlanta. To smooth the seasonal cycle of agriculture, the FRBA projected that it would rediscount bills of its member banks, enabling them to provide more credit to their farmer-customers during the peak season of planting and at times when crop prices were low so that they would not have to dump their crops. In addition, the Atlanta Fed believed that it could strengthen the cotton economy by lessening its dependence on New York banks.

As early as 1915, the minutes of the Board of Directors of the Federal Reserve Bank of Atlanta record interventions that moved well beyond the role specified for a Federal Reserve bank in the Federal Reserve Act. Concerned about the weak condition of the Third National 
Bank of Fitzgerald, Georgia, the Board expressed a "willingness to help if it can be done with safety," as assistance "would not only probably save this institution but would redound to the best interests of the Federal Reserve System." (FRBA, Board of Directors minutes, May 14, 1915). A Federal Reserve bank director and the head of the Credit Bureau visited the bank with authorization to discount up to $\$ 15,000$ of the bank's paper and to obtain the assistance of neighboring banks in providing another $\$ 15,000$ and hopefully $\$ 20,000$ in discounts. As part of this operation the Third National Bank had to consent to the placement in the bank of an individual chosen by the Atlanta directors who would represent the interests of the Federal Reserve bank (FRBA, Board of Directors minutes, May 14, 1914). Ultimately, the bank had to be rescued. The minutes of July 8, 1915 reported that the bank's capital had been wiped out by bad debts and loans, and that the Federal Reserve bank assisted with a new subscription of capital stock for a reorganized bank. Subscribers to the new capital stock agreed to pay part in cash and part in notes, of which $\$ 50,000$ to $\$ 55,000$ could be discounted immediately at the Federal Reserve bank.

Discounting gave the Atlanta Fed a window into some potentially troubled banks that seemed to using credit from the Fed to stay afloat. In early 1915, the Executive Committee of the Board of Directors rejected $\$ 28,000$ of the $\$ 71,400$ notes that Heard National Bank of Jacksonville, Florida had presented for discount, and again three months later it rejected $\$ 54,000$ of the $\$ 113,796$ notes presented. (FRBA, Executive Committee minutes, January 15 and March $23,1915)$. Finally in November it refused a request for $\$ 25,000$, stating that the committee felt "that sufficient accommodations had already been granted to said bank" (FRBA, Executive Committee minutes, November 26, 1915). In 1916, the FRBA's governor, Maximilian B. Wellborn was called to Washington D.C. for a meeting with Board Governor Harding and the Comptroller John Skelton Williams about the Heard National Bank. The OCC's chief district examiner had found that Heard had sustained loan losses of $\$ 700,000$ to $\$ 800,000$, dwarfing its reported losses of $\$ 250,000$. At the behest of the OCC and with the apparent blessing of the Federal Reserve Board, the FRBA's cashier, J.P. Pike was made vice president of the bank with effective control wrested from the president who remained as a figure head. The FRBA also agree to discount up to $\$ 500,000$ for the Heard bank, which the Atlanta Fed's Board of Directors approved (FRBA Board of Directors minutes, August 10, 1916). But, even this remedial action did not save the Heard National Bank, which failed and left the FRBA with a substantial loss (FRBA Board of Directors minutes, April 25, 1917). 
Yet, while the Third National and the Heard National received special assistance, other banks like the Island City National Bank of Key West, Florida apparently did not. The Board was primarily concerned that Island City's notes discounted at the Fed were past due. The Island City bank received a special inspection by cashier J.B. Pike, but was then liquidated under the authority of the OCC (FRBA Board of Directors minutes, September 15 and October 15, 1915). Such an intimate involvement in the management of banks was not contemplated by the Federal Reserve Act, although clearing houses had sometimes provided similar assistance (Friedman and Schwartz, 1963). In discussions of these banks in the FRBA's directors minutes, there is no reference to any threat to financial stability or any statement of a rule for intervention, making it appear that these were discretionary actions that today would be deemed likely to induce moral hazard. However, as they only involved a few banks and were not part of a systemic problem, they attracted little notice. In fact, as noted above, the Board appears to have encouraged intervention some cases. This state of affairs changed abruptly when the recession of 1920-1921 hit, and many more banks in the district were threatened by failure. As the problem was districtwide, the FRBA's efforts to save them drew upon the resources of other Federal Reserve banks and created a furor within the system.

\section{Protecting District Financial Stability: the Atlanta Fed and the Recession of 1920-1921}

The greater severity of the recession of 1920-1921 in the Sixth District and the predisposition of the Atlanta Fed to assist struggling banks set up a confrontation with the Federal Reserve Board, which was convinced that a large deflation was necessary to reduce the price level and ensure the "liquidation" of loans by Federal Reserve banks to their member banks. What is surprising is how little of the conflict over policy was seen outside of the Fed. In the Atlanta Fed's Annual Reports, there was no evidence of the pressure that the Board had put on the FRBA to contract its balance sheet. The 1920 Report blandly stated: "Probably never in the history of this country has its financial structure been so severely tried as during 1920, certainly the Federal Reserve System has received a most severe test, and successfully performed the functions for which it was inaugurated." (FRBA, Annual Report 1920, p. 7). Similarly, the Federal Reserve Board's Annual Report for 1922 records the extraordinary interregional bank transfers but gives little hint at the struggle between the Federal Reserve banks in heavily agricultural regions and the rest of the System. 
The most detailed public account is found in Harding's memoir (1925), which provides a neutral description of the 1920-1921 deflation with no hint of the internal conflicts with the Fed. Harding wrote:

Because of the low reserve percentage of the banks and of the constant tendency of balances to shift from one Federal Reserve District to another, it had become necessary in 1919 to resort to large and frequent rediscount transactions between the Federal Reserve Banks themselves. Such transactions increased both in frequency and in volume during the year 1920 and continued in a smaller degree for several months in 1921." (Harding, 1925, p. 182).

After listing the lending and borrowing Reserve Banks, Harding then commented:

The banks, however showed such a spirit of cooperation that no compulsion was ever necessary, although there were times when at least one of the banks (Cleveland) was rediscounting larger amounts for other Federal Reserve Banks than it was for its own member banks. No application of a Federal Reserve Bank for rediscount accommodation was ever declined. (Harding, 1925, p. 183).

Defending the Fed from a charge "in the halls of Congress and elsewhere of the "murderous deflation' alleged to have taken place during the year 1920," (Harding, 1925, p. 183), Harding presented a table to show that there was "no contraction of credit or currency during that year," by which he meant no decline in bills discounted or notes in circulation for the year 1920 for the whole system. But, while bills discounted increased from $\$ 2.1$ to $\$ 2.7$ million bills purchased dropped from $\$ 561,313$ to $\$ 255,702$. Of course, this narrow frame covers only part of the recession that the NBER dates from January 1920 to July 1921 (NBER, www.nber.org, Business Cycle Dates). Between end-of-year 1919 and 1920, there was a 21 percent increase in bills discounted, but this was followed by a drop of 57 percent the next year, most of this coming from agricultural districts (Board of Governors, 1943, Table 87).

Even recent researchers treat the operation of the Federal Reserve System in this period as cooperative and almost seamless. To offer historical perspective on the debate over TARGET2 imbalances between the national central banks of the Euro, Eichengreen, Mehl, Chitu and Richardson (2014) examined the period 1913-1960 and claim that mutual assistance between Reserve banks was common, stating:

Fortunes could changes quickly with earlier emergency recipients of gold turning into providers. Imbalances did not grow endlessly but narrowed once shock subsided. Mutual assistance did not excite experts or the American public, nor in most cases did they trigger insurmountable tensions between regions (Eichengreen, et. al., 2014, p. 5). 
Citing the 1920 Annual Report of the Federal Reserve Board, they view this cooperation as arising out of wartime patriotism "there has...been such a spontaneous spirit of cooperation between the Federal Reserve Banks that all transactions suggested by the Federal Reserve Board have been made voluntarily." While this selfless accommodation by Federal Reserve banks may have been typical during the World War I or the post-World War II, it did not characterize some earlier years. In particular, the recession of 1920-1921 weighed unevenly among regions; and inter-Federal Reserve district assistance was vigorously contested.

The dimensions of the regional stress experienced by the Federal Reserve banks during the recession of 1920-1921 are mapped out in Figure 3 from the January 1922 Federal Reserve

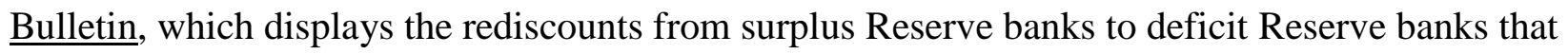
effected transfers of gold certificates through the Gold Settlement Fund and enabled the latter to maintain their legal minimum gold reserve requirements. The uneven regional effects of the recession are clear as inter-district accommodation rose during the contraction, peaking at \$280 million in October 1920. This sum was considerable as it was larger than the total assets of many Federal Reserve banks; the Atlanta Fed for example, had total assets of $\$ 275$ million at the end of December 1920.

In the early months of the recession, from January through March 1920, most demand for accommodation came from the New York and Philadelphia Federal Reserve banks, with several other Federal Reserve banks supplying gold certificates. This pattern may be explained by the international gold losses, primarily in New York, which gave rise to the New York Fed's urgent demands for a rise in discount rates that moved from 4 3/4 to 6 percent on January 23, 1920. But, for the remainder of the year, after the first quarter, there was a clear regional division between agricultural and non-agricultural Federal Reserve districts. From March through December 1920, the Federal Reserve banks of Richmond, Atlanta, Chicago, St. Louis, Minneapolis, Kansas City and Dallas, continuously required accommodation from Philadelphia, Cleveland, and San Francisco. The New York Fed provided surplus gold reserves from April through July but then required modest assistance for the rest of the year (Federal Reserve Bulletin January 1922, p. 29). By far, the largest supplier of reserves to deficit districts was the Federal Reserve Bank of Cleveland. For example, at the end of October 1920, total accommodation reached \$260 million, of which Cleveland supplied $\$ 139$ million, followed by Boston giving $\$ 84$ million and Philadelphia \$21 million. The Atlanta Fed was one of many borrowers; its peak borrowing was $\$ 45$ million in September, which was also the month that borrowing by the Dallas Fed hit a high 
of \$37 million. In October, the Kansas City Fed reached \$45 million, St. Louis \$37 million, and Minneapolis, \$26 million----with the New York Fed also drawing \$61 million from other districts.

Figure 3

Federal Reserve Inter-District Accommodation, 1920-1921

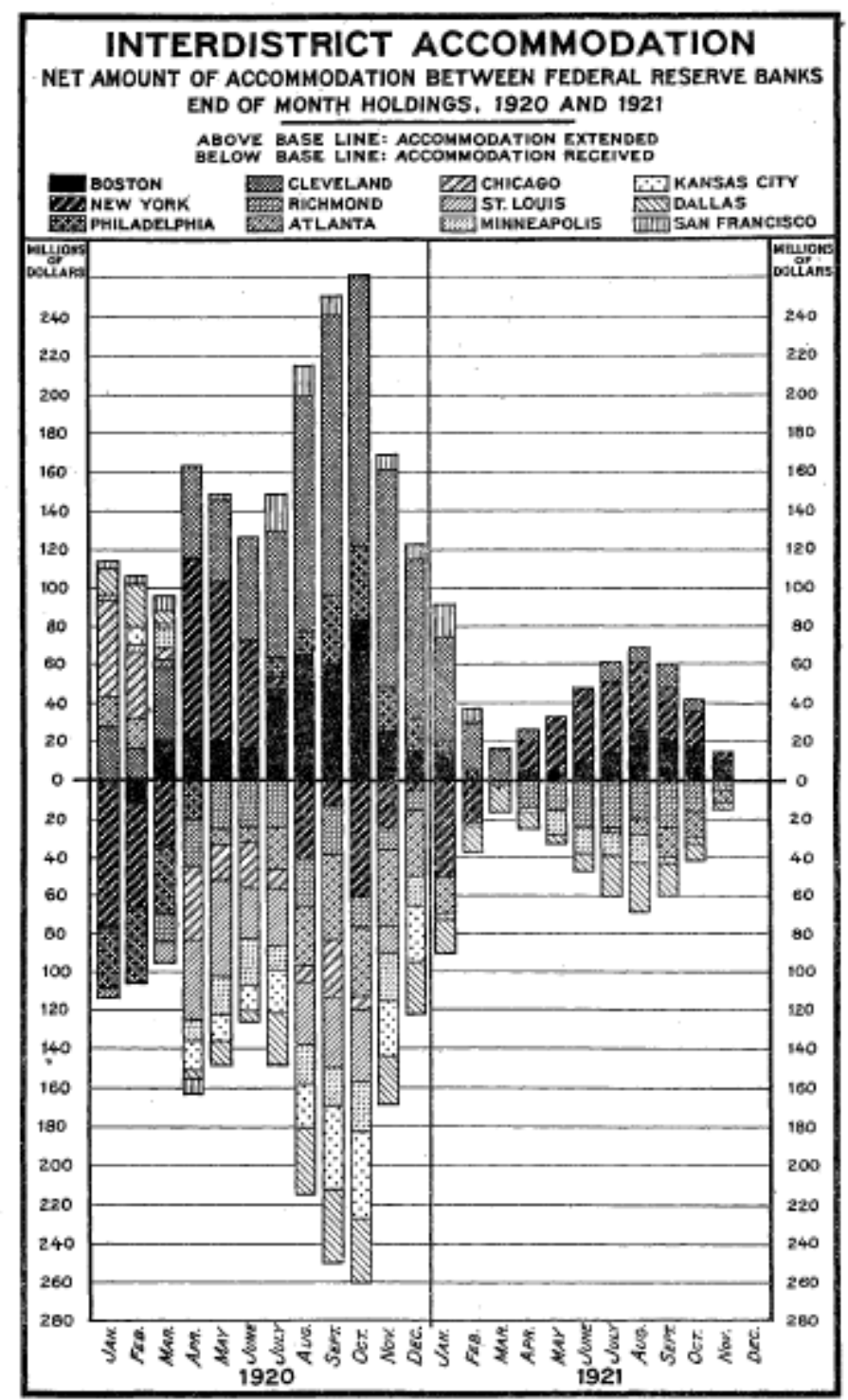

Source: Board of Governors of the Federal Reserve System, Federal Reserve Bulletin (January 1922), p. 28. 
Table 1

Balance Sheet, Reserves and Borrowings of the Atlanta Fed

\begin{tabular}{|c|c|c|c|c|c|c|}
\hline Month & $\begin{array}{l}\text { Total } \\
\text { Assets } \\
\text { \$M }\end{array}$ & $\begin{array}{l}\text { Bills } \\
\text { Discounted } \\
\text { and } \\
\text { Purchased }\end{array}$ & $\begin{array}{l}\text { Reserve } \\
\text { Ratio }\end{array}$ & $\begin{array}{l}\text { Adjusted } \\
\text { Reserve Ratio }\end{array}$ & $\begin{array}{l}\text { Total } \\
\text { Discounts } \\
\text { for other } \\
\text { FRBs \$M }\end{array}$ & $\begin{array}{l}\text { Total } \\
\text { Discounts } \\
\text { from other } \\
\text { FRBs \$M }\end{array}$ \\
\hline January-1919 & & 86 & $45.7 \%$ & & & 3.1 \\
\hline February-1919 & 197 & 83 & $47.9 \%$ & & & \\
\hline March-1919 & 206 & 89 & $45.7 \%$ & & & \\
\hline April-1919 & 201 & 89 & $45.4 \%$ & & & \\
\hline May-1919 & 209 & 89 & $46.9 \%$ & & & \\
\hline June-1919 & 203 & 93 & $43.7 \%$ & & & \\
\hline July-1919 & 215 & 85 & $49.9 \%$ & & & \\
\hline August-1919 & 209 & 102 & $40.1 \%$ & & & \\
\hline September-1919 & 224 & 104 & $41.4 \%$ & & & 12.3 \\
\hline October-1919 & 256 & 119 & $40.7 \%$ & & & 5.5 \\
\hline November-1919 & 264 & 115 & $46.0 \%$ & & & \\
\hline December-1919 & 280 & 110 & $52.8 \%$ & $56.7 \%$ & 5.1 & 5 \\
\hline January-1920 & & 106 & $48.5 \%$ & $56.0 \%$ & 15 & \\
\hline February-1920 & & 110 & $44.2 \%$ & $52.2 \%$ & 16.2 & \\
\hline March-1920 & & 116 & $48.3 \%$ & $50.0 \%$ & 3.4 & \\
\hline April-1920 & & 112 & $41.4 \%$ & $41.4 \%$ & & \\
\hline May-1920 & & 123 & $40.4 \%$ & $36.2 \%$ & & 8.5 \\
\hline June-1920 & & 120 & $40.6 \%$ & $36.1 \%$ & & 7.9 \\
\hline July-1920 & & 119 & $40.8 \%$ & $29.3 \%$ & & 21.6 \\
\hline August-1920 & & 120 & $40.4 \%$ & $23.5 \%$ & & 31.9 \\
\hline September-1920 & & 122 & $40.5 \%$ & $17.0 \%$ & & 45.5 \\
\hline October-1920 & & 127 & $40.5 \%$ & $24.2 \%$ & & 36.1 \\
\hline November-1920 & & 145 & $40.1 \%$ & $21.2 \%$ & & 40.2 \\
\hline December-1920 & 275 & 139 & $40.7 \%$ & $24.8 \%$ & & 33.7 \\
\hline January-1921 & 261 & 135 & $42.2 \%$ & $28.7 \%$ & & 31.9 \\
\hline February-1921 & 259 & 129 & $42.7 \%$ & $42.7 \%$ & & \\
\hline March-1921 & 252 & 123 & $42.0 \%$ & $42.0 \%$ & & \\
\hline April-1921 & 244 & 116 & $46.0 \%$ & $46.0 \%$ & & \\
\hline May-1921 & 245 & 110 & $46.4 \%$ & $46.4 \%$ & & \\
\hline June-1921 & 232 & 101 & $44.4 \%$ & $44.4 \%$ & & \\
\hline July-1921 & 220 & 106 & $41.6 \%$ & $39.5 \%$ & & 13.5 \\
\hline August-1921 & 206 & 100 & $40.8 \%$ & $35.6 \%$ & & 8.9 \\
\hline September-1921 & 222 & 108 & $40.4 \%$ & $29.4 \%$ & & 16.8 \\
\hline October-1921 & 211 & 104 & $40.3 \%$ & $32.3 \%$ & & 14.1 \\
\hline November-1921 & 205 & 97 & $40.5 \%$ & $35.9 \%$ & & 7.4 \\
\hline December-1921 & 215 & 95 & $42.6 \%$ & $42.6 \%$ & & \\
\hline
\end{tabular}

Sources: Federal Reserve Bank of Atlanta, Annual Reports (1919, 1920, 1921); Board of Governors Minutes (19191921), daily balance sheets. Federal Reserve Bulletin (January 1922).

Note: The adjusted reserve ratio subtracts reserves borrowed from other Federal Reserve banks. 
Yet, from the archival records available, it appears that Atlanta received the harshest criticism from the Federal Reserve Board, responding to complaints by the Cleveland Fed. In terms of reserve ratios for its Federal Reserve notes, the Atlanta Fed was not the worst offender. In the difficult month of September 1920, the FRBA had a reserve ratio of 40.5 percent. But when borrowed reserves were subtracted, the "adjusted" reserve ratio would have been 17 percent. For all other months, its adjusted reserve ratio was above 20 percent. Other Federal Reserve banks fell below this 20 percent mark more frequently; St. Louis, Minneapolis, and Kansas City were below it for 2 months in 1920. The Dallas bank was probably the weakest, with its adjusted reserve ratio falling below 20 percent for the last six months of 1920, then hitting just 10 percent in September 1920.

What may have made Atlanta the center of attention was its willingness to increase bills purchased and discounted from member banks, significantly expanding its balance sheet in the difficult months of 1920. Table 1 presents some monthly data for the FRBA, drawn from a variety of sources, primarily the daily balance sheets preserved in the Reserve banks' library. Unfortunately, these balance sheets for the critical year of 1920 are missing, but some of the monthly data can be reconstructed from other sources. During 1919, when the postwar boom rapidly picked up steam, bills discounted and purchased by the FRBA increased from $\$ 86$ million to $\$ 110$ million, with the reserve ratio generally remaining well above the 40 percent minimum. Its overall, balance sheet grew from under $\$ 200$ million to $\$ 280$ million. The value of bills discounted and the official and adjusted reserve ratios are shown in Figure 4, with the recession of 1920-1921 shaded in gray.

Heading into the recession in 1920, the Atlanta Fed did not "liquidate" member bank borrowings but expanded them, peaking at $\$ 145$ million in November 1920, as seen in Table 1 and Figure 4. As members drew on these loans, the Federal Reserve bank's reserves dropped and the reserve ratio would have fallen below the legal minimum if the bank had not received accommodation for other Federal Reserve banks. By 1921, the Atlanta Fed was shrinking its balance sheet and liquidating member bank borrowing; but it could not halt the drain in reserves. With the economy still in the downward phase of the recession until July 1921, it again required accommodation from other Federal Reserve banks between August and November 1921.

Unfortunately, only the minutes of the Federal Reserve Bank of Atlanta's Board of Directors and its Executive Committee were available and the discussions and correspondence of the officers and members of the Boards of the remaining eleven Reserve banks are largely 
unexplored. The Atlanta minutes reveal that cooperation between Reserve banks was often grudging and hesitant. While in the words of Governor Wellborn, its Governor, the Federal Reserve bank was "caring for the demands of member banks," trying to stave off a banking collapse, it was subjected to considerable pressure to rapidly "liquidate" its discounts and advances to member banks. Grateful member banks were buffered. J.R. Morgan, the cashier (chief financial officer) of the Bank of Union Springs Alabama described the Atlanta Fed's actions from a cotton bank's point of view:

Figure 4

Response of the Atlanta Fed to the Cotton Crash

Bills Discounted and Reserve Ratios, 1919-1921

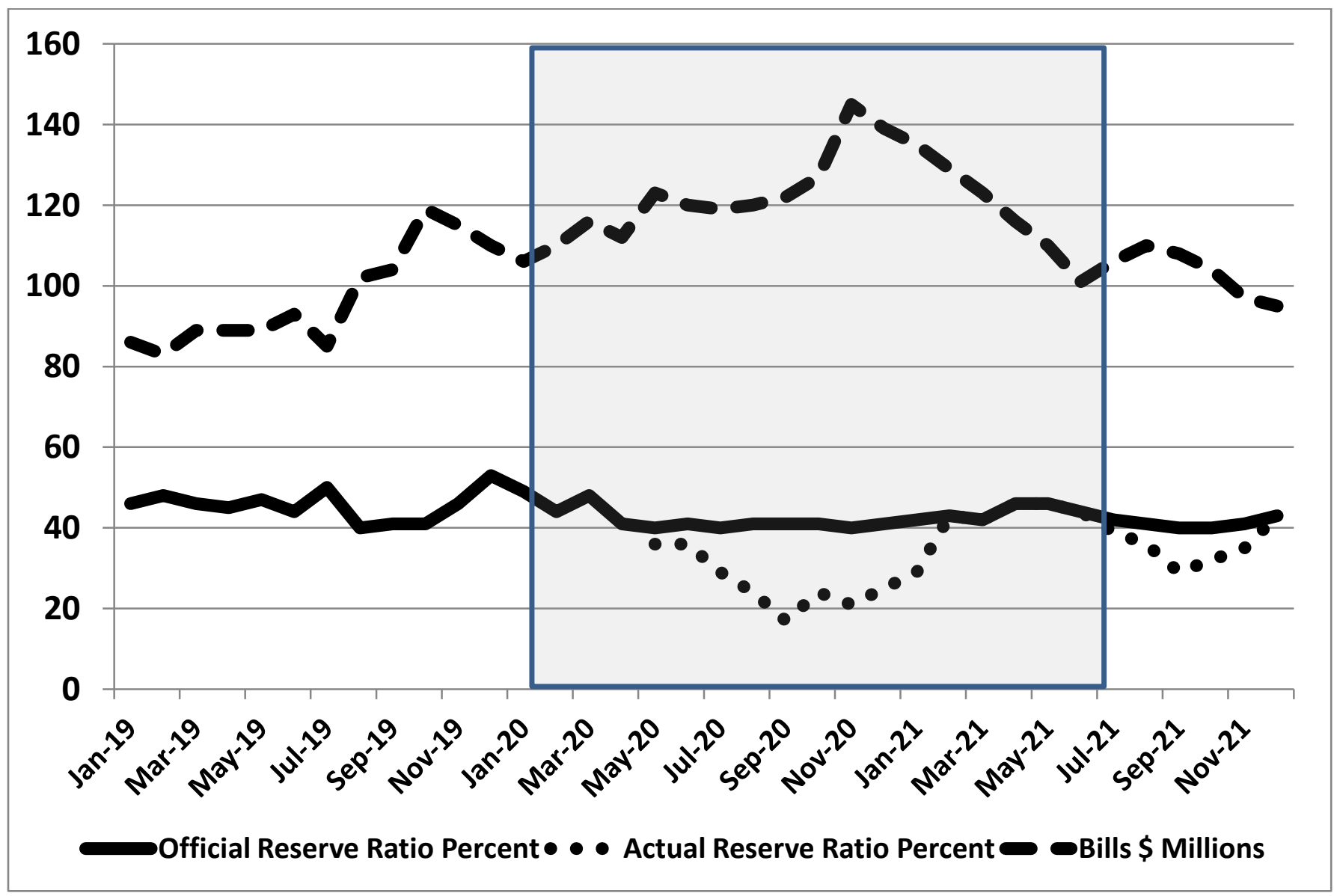

Source: See Table 1

All we country bankers could do was endorse notes and send them to the Federal Reserve. Governor Wellborn met every legitimate demand....For its duration it was the worst we ever had, though it only lasted six to eight months. Governor 
Wellborn broke it by throwing the whole resources of the Federal Reserve behind the banks of the south (quoted in Garrett, Chapter 9, undated).

As the depth of the recession became apparent in the summer of 1920, Wellborn reported to the Atlanta Fed's Board of Directors:

Your Executive Committee feels that in order to effectually cooperate with the Federal Reserve Board in their earnest efforts towards deflation and control of credits, that it is necessary and essential that we rely not only on repeated admonitions to member banks, but that we continue to exercise that discretion permissible under the law as to the desirability of certain paper, and especially the frequency and volume of discount transactions of certain members banks with the Federal Reserve Bank. (FRBA Board of Directors minutes, August 6, 1920)

The leaders of the Atlanta Fed viewed themselves as tough but were uncomfortable about carrying through a "liquidation" of loans as encouraged by Washington, D.C. In the FRBA Board's July meeting, it was noted that some banks were angry because they had been forced to pay off their loans from the FRBA, even though they were offered the chance to keep the loans by posting more collateral. Wellborn described one group of loans that the Reserve bank wanted off of its books.

A statement of borrowing by textile people, especially hosiery mills, in the Chattanooga district, shows that we have a total of $\$ 927,000$, and while the aggregate amount involved is not very excessive, still it is quite large for one community. The mills claim that jobbers are holding off, consequently very few sales are being made. We feel that it would probably be best that we begin to insist on a gradual liquidation of this class of paper. (FRBA Board of Directors minutes, August 6, 1920).

Still, Wellborn felt that too much pressure was being placed on the Atlanta Fed by Washington. In particular he voiced the Board of Directors' frustration that other districts had a 5 percent discount rate approved by the the Federal Reserve Board, while the Atlanta Fed had a 6 percent rate. He commented, "it seems to me that our rate should be on a level with theirs and a reduction made for the same reason that theirs was made - that is, to stimulate and encourage a revival of businesses." (FRBA Board of Directors minutes, October 8, 1920).

While the Federal Reserve Board may have tolerated accommodation for troubled banks in first years of the Fed, by the end of 1920, the Federal Reserve Board and several Reserve banks believed that the Atlanta Fed ought to be reined in. On December 3, 1920, Harding wrote a letter to Wellborn about the Federal Reserve Board's alarm at the FRBA's interbank 
borrowing, singling out the fact that it had borrowed $\$ 35$ million from the Federal Reserve Bank of Cleveland, while the FRBA had only $\$ 11$ million capital and surplus. Minimizing the problems of banks in the South, Harding sternly told Atlanta that:

The Board is of the opinion that your present experience should convince you that your lending policy has been rather too lenient and that in some cases credit was granted in such large amount to banks when no emergency existed as to impair your ability to make loans out of your own resources when a real emergency did arise. ${ }^{8}$

Noting that to continue lending to Atlanta, Cleveland might have to borrow from other banks, he appeared to threaten Atlanta: "Here again I may say that I do not believe the Board would permit such transactions to take place but would be more inclined to allow the reserve of the Atlanta Bank show a depreciation." What this meant was unclear, especially as par clearance was mandated by the Federal Reserve Act, but it was a chastisement in the ordinarily courtly language of the Fed.

On December 9, 1920, Wellborn wrote back to Harding with a spirited defense of the Atlanta Fed's actions in the face of "the increased restlessness of the Cleveland bank," arguing that the regional economies were too tightly integrated to allow a disaster to occur in one and not expect severe repercussions throughout the whole. Wellborn emphasized the magnitude of the shock from the drop in cotton prices, stating that "No section of our country could stand the full unmitigated shock of such a disaster without ruin." Then, he made his appeal:

I submit, if this bank had failed to stand as a buffer between the business of this section and disaster, it would not only have failed in its duty, but it would have permitted a situation to develop which would have seriously affected all other sections of the country and every other reserve bank. To carry the load under these emergency conditions of course mean borrowing and rediscount...... This bank does not consider that its efforts along these lines have been directed at the stimulation of an artificial price. We have not undertaken to draw upon the reserves or the resources of other sections, to hold our crops for artificial or inflated prices..........In such a situation the Atlanta bank does not stand as a private business venture, asking for credit for itself alone, or for the purpose of making profits. The bank stands as a public institution, designed within limited and legitimate lines to prevent disaster........ The commerce of all the states are too closely knit together to permit the confining of the results of financial upheaval to any one particular state or group of states. The Cleveland District

\footnotetext{
${ }^{8}$ These letters are recorded in the FRBA Board of Directors minutes for the December 10, 1920 meeting.
} 
itself, counts this section one its principal markets. The Sixth District is filled with farm implements, trucks, automobiles and other manufactured products emanating from the Cleveland District. The commercial banks of the Sixth District have financed the local dealers [of] many of these commodities, that such local dealers might pay cash to the manufacturers in the Cleveland District. To shut off completely, or hamper the buying power of this and other agricultural districts, would bring about a situation which would be felt from the Pacific to the Atlantic. (FRBA, Board of Directors minutes, December 9, 1920)

Wellborn then criticized the Cleveland bank for taking a parochial position and the rest of the Federal Reserve System for its short memory:

In the present crisis it seems to me it is not a time for individual reserve banks, which are rediscounting for other reserve banks, to attempt to impose upon the borrowing bank, onerous conditions. If the Cleveland bank is "restless" on account of the credit which it has in the past, and must almost of necessity in the future, on account of its high reserve position, extend to Atlanta, the Cleveland bank simply takes a rather narrow and personal view of the situation....... May I not be permitted to call your attention to the fact that last winter and spring when your Board called upon the Atlanta bank to rediscount for New York, Boston and Philadelphia we did not raise any objection....we did not think it proper to ask any questions because we recognized that your body was the sole judge of the expediency and that you had the full authority to compel interbank rediscounting. (FRBA Board of Directors minutes, December 9, 1920)

As for the vague threat that Harding had made in his letter of December 3, Wellborn pointed out the potentially calamitous consequences of exposing to the public the awkward position of the Atlanta Fed or allowing a "depreciation."

With regard to your statement that your Board has "an inclination to allow the Atlanta bank show a depreciation." I do not question that your Board has a legal right to do this, but it is a responsibility that rests upon your Board, and in these perilous times I hardly think your Board would care to assume such a fearful risk. The mere publication of our actual reserve position might possibly have the effect of causing the failure of numerous banks, not only in this District, but in others as well, and bring on a panic of great magnitude. (FRBA Board of Directors minutes, December 9, 1920)

When Harding responded on December 15, 1920, his letter was more focused on when the Atlanta Fed would begin to reduce its rediscounts. He began by commenting: "In your letter you do not express any opinion as to when your bank will be able to pay off its rediscounts without falling below its legal minimum reserve, and on the other hand, you assume that it will be necessary for other Federal Reserve banks to extend your bank accommodation for an 
indefinite period." Moderating his tone, Harding stated that the "Board at no time suggested drastic and immediate liquidation but has repeatedly reiterated its preference for orderly processes." Still Harding let Wellborn and the Atlanta Board know that the Federal Reserve Board thought that the Atlanta Fed had taken on excessive risks:

The Board has never advised farmers to produce a larger crop of cotton and does not, therefore, coincide with your view that the Federal Reserve Bank should carry loans indefinitely for member banks until cotton reaches a price that is satisfactory to the producers. As a matter of fact your reports indicate that you are not carrying an excessive amount of cotton for member banks and our statements show that you are well margined on what you are carrying. An analysis of the list of your large borrowing banks, which you sent in your letter of December $10^{\text {th }}$ shows that seven banks in your district, located in commercial and industrial centers, are borrowing $\$ 71,8034,469$, and that you are lending to each of four banks an amount in excess of the total capital and surplus of your own bank. Since the loans to these banks constitute a large proportion of your total loans, the Board is forced to the conclusion that your credit situation is not caused entirely by agricultural conditions. (FRBA, Board of Directors minutes, December 15, 1920)

While accepting that the FRBA would not be able to quickly reduce its interbank loans, Harding told the Atlanta officials that they should write directly to borrowing banks to reduce their lines of credit and that the Atlanta Fed should provide an additional 15 percent margin of collateral for the Cleveland loans in form of commercial paper.

Wellborn replied on December 23, 1920 that it was impossible to forecast when liquidation of its loans would take place as only three-quarters of new cotton crop has been sold. As for the banks that Harding identified as untroubled by cotton loans, Wellborn pointed out that the large borrowings of the city banks were a result of the fact that they had provided accommodation to their country correspondent banks---often state banks who were not members of the Fed---for production and marketing of the cotton crop. Not all banks had joined the Fed and thereby gained direct access to the discount window. Only 85 of the 1609 state banks in the Sixth District were member banks; credit to them was being intermediated by the city banks. Hence, low cotton prices threatened all banks. In Wellborn's opinion, the Atlanta Fed had a broad responsibility for the whole of the financial system in the Sixth District not just the member banks because of the highly interconnected nature of the banking system (FRBA Board of Directors minutes, December 23, 1920). 
Finally, winding up this exchange, Wellborn condemned any effort to rapidly reduced credit that might risk a fire sale and banking crisis. The Atlanta Fed only gave borrowers modest extensions after the "bulk of farmers' notes fell due, and our policy is merely to give them reasonable time to find a market in these disturbed times, in order to keep them from 'dumping' their products on the market at one time." (FRBA, Board of Directors minutes, December 23, 1920). As to whether the Atlanta Bank had was acting correctly, Wellborn quoted an April 10, 1920 speech of Dr. Mill of Federal Reserve Board:

Credit control to my mind, therefore, at this juncture does not mean contraction. It means preventing a further expansion, except as that further expansion can be definitely validated by the necessities of industries that are contributing to the sum-total of goods in the country...I think that forced contraction or liquidation might be one of the most disastrous of things. (FRBA, Board of Directors minutes, December 23, 1920).

While Wellborn offered a spirited defense of the Atlanta Fed's actions, the bank did begin a liquidation of member bank borrowings and shrank its balance sheets as viewed in Table 1 and Figure 4. At the first meeting of 1921, Wellborn told his Board that "Quite a large number of our member banks have rediscounted more than two or three times their capital and surplus. Write to them that they must reduce their borrowings." (FRBA Board of Directors minutes, January 14, 1921). By the March meeting, he reported that (adjusted) reserves had risen from $37.6 \%$ on February 8 to $44 \%$ on March 8; this rise was brought about largely by liquidation of $\$ 9.9$ million of member bank borrowings by the Atlanta Fed's branch in New Orleans (FRBA Board of Directors minutes, March 11, 1921).

Nevertheless, the Atlanta bank remained very active, hoping to avoid large bank failures. In the Board's March 11, 1921 meeting Wellborn described how the FRBA had helped to manage the absorption of the weak Citizens and Southern Bank of Savannah by the Hibernia Bank, which assumed all of its liabilities and assets. The absorption was handled "by the tact and good management of Mr. Campbell," the Deputy Governor of the Atlanta Fed (FRBA Board of Directors minutes, March 11, 1921), but it needed assistance. In addition to obtaining \$2 million via bills payable to other banks, Hibernia obtained over half of a million in discounts from the FRBA.

The pressure brought to bear on the Atlanta Fed induced it to shrink its lending had political repercussions. In July 1921, Congress launched the Joint Commission of Agricultural Inquiry to investigate the causes of agriculture's distress. The Federal Reserve Board was grilled 
and appears, as a result, to have changed its attitude. On July 20, the Board held a conference with the Reserve bank presidents in the cotton growing districts---Richmond, Atlanta, St. Louis, Kansas City and Dallas. At the end of the meeting an announcement was issued that the Federal Reserve banks “

in addition to credits already extended, are able and stand ready to extend further credit for the purpose of harvesting and marketing the coming crop, in whatever amount may legitimately be required, either directly to their member banks or, under a ruling now issued by the Federal Reserve Board, indirectly to nonmember banks acting through the agency and with the indorsement of a member bank." (Joint Commission, Vol. 2, pp. 346-347).

The new release emphasized the "urgency of rendering all proper assistance to" cotton dealers and producers "during such abnormal times." Ironically, this new policy was announced just as cotton prices were recovering quickly as illustrated in Figure 2. Rural banks in cotton and other agricultural regions remained weak and experienced high but declining rates of failure, and the urgency of action faded.

In the second half of 1921, the FRBA continued to provide new forms of assistance to its many troubled member banks. To help weak banks generally, Wellborn proposed to the Atlanta Board a plan to execute repurchase agreements for U.S. Government war bonds with members banks because their holdings were disproportionately large relative to their capital and surplus. As interest rates had risen, bond prices had fallen and member banks might incur losses that would impair their surplus or even capital, when examiners marked their portfolios to market. In addition, holdings of these bonds lowered earnings because the coupon rates were lower than the discount rate. In order to "minimize such losses to the member banks and enable them, in a measure, to amortize the carrying value down to the market value the Officers of the Federal Reserve Banks......hereby authorize, acting under Sect. 14 of the Federal Reserve Act" to execute a 60 day repurchase agreements for bonds that are in excess of a member bank's capital and surplus. Every 30 days, banks would pay the Federal Reserve bank 1/10 of 1 percent of aggregate principal amount of the bonds, until payments equaled the loss represented by the market price (FRBA Board of Directors minutes, August 12, 1921).

Some banks still suffering from the after effects of the recession received special attention. The FRBA sought to ensure that they would be healthy enough to resume normal operations. One example of this activity occurred in December 1921. In consultation with the Chief National Bank Examiner John W. Pole and Atlanta Fed's Assistant Cashier J.B. Tutwiler, 
Wellborn decided to help First National Bank of Colquitt whose capital stock was wiped out. The bank examiner was of the opinion that maintaining the bank would have a favorable influence on the general market for the financial instruments it bought and discounted. He believed that it was unlikely that the Colquitt bank would realize to 20 cents on the dollar for its underlying collateral if it were closed, but more it if continued as an ongoing bank. In response, the Atlanta Fed released the Colquitt bank from repayment of $\$ 30,000$ of bills receivable that the FRBA had discounted and purchased $\$ 84,000$ of doubtful assets from the bank for sum of $\$ 30,000$ that it was releasing (FRBA Board of Directors minutes, December 7, 1921).

In the last meeting of the Board of Directors of the Atlanta Fed for 1921, Wellborn summarized his vision of the task of the Reserve bank:

The daily problem which our Executive Committee must meet, is that of properly taking care of those of our member banks which are in straightened condition. Many of those banks have been very heavy borrowers through the year; and, while this season of the year would naturally demand that there be curtailment, deposit declines are in larger volume that in collections....The reports of examination of such banks are watched very closely, and the paper they offer for rediscount is scrutinized to the last degree. (FRBA, Board of Directors minutes, December 7,1921$)$

Wellborn had not retreated from the position that he had set forth in his exchange of letters with Harding a year before, stating that, "I feel that it is the duty of our Committee to sustain and back up to the furthest point possible, our member banks, by accepting their paper for rediscount where it is reasonable to do so." He posed the regional central bank's dilemma thusly:

On the one hand, we are confronted with the danger of extending so much aid to a member bank that, if it failed we should incur a very considerable loss..... On the other hand, if we go to a great length and save a member bank so that it can, in time, work out of its difficulties, I feel that we would be accomplishing what was intended in the establishment of the Federal Reserve System. It is our fundamental duty to take care of extremes and emergencies and while the responsibilities are exceedingly heavy, still I believe that we should show the proper nerve and fortitude, and go as far as is possible in saving any member bank which is in difficulty. (FRBA Board of Directors minutes, December 7, 1921)

\section{Afterwards}

Some officials who had opposed Wellborn's strategy later conceded that he had acted wisely. D.W. Crissinger who had been the Comptroller of the Currency and became Chairman of the Federal Reserve Board in 1923 commented: "We were inclined at first to disagree with 
Governor M.B. Wellborn of the Atlanta bank, in some of the policies which he pursued, but...he was right and we---the members of the federal reserve board---were wrong." (quoted in Gamble, 1989). Certainly Wellborn's Sixth District constituency and many influential Southern Congressmen were satisfied with his stewardship of the Atlanta Fed. When Congress held hearings into allegations that the Federal Reserve had aided speculators in the cotton crash, Wellborn was lauded by senators from the Cotton South. (Gamble, 1989).

In modern debates over whether a central bank should do more than flood the market with liquidity during a crisis, Wellborn and the Atlanta Fed stand in the corner of the interventionists. Their concern focused on the threat that a sharp drop in liquidity would force a crisis-inducing fire sale of bank assets. They believed that the Reserve bank should intermediate reserves from other districts, supplying liquidity directly to its member banks and indirectly to the non-member banks. Thus, financial stability would be preserved in the absence of a responsive interbank market for funds. Nowhere in the Minutes of the Board of Directors of the Sixth District Reserve bank is there a discussion of the problem of moral hazard that modern non-interventionists have emphasized. Wellborn saw the collapse of the post-World War I boom as an exceptional event that would not be repeated; a fact, that he believed the District's banking community understood well. His member banks had not acted recklessly but patriotically by expanding credit during and after the Great War; some may have offered excessive credits during the boom but he regarded this behavior as a minor factor. Consequently, the Atlanta Fed should have accommodated its member banks during the harsh recession and readied them to resume normal operations in the 1920s. Of course, what he did not anticipate was that a second and even greater shock would occur a decade later. 


\section{Bibliography}

Allen, Franklin and Douglas Gale, "Interbank Market Liquidity and Central Bank Intervention," Journal of Monetary Economics 56 (2009), pp. 639-652.

Board of Governors of the Federal Reserve System, Banking and Monetary Statistics, 1914-1941 (Washington, D.C., 1943).

Board of Governors of the Federal Reserve System, Federal Reserve Bulletin (January 1922).

Bordo, Michael D. and David C. Wheelock, "The Promise and Performance of the Federal Reserve as a Lender of Last Resort, 1914-1933," in Michael D. Bordo and William Roberds, eds., A Return to Jekyll Island: The Origins, History and Future of the Federal Reseve (Cambridge: Cambridge University Press, 2013), pp. 59-98.

Caballero, Ricardo J. and Alp Simsek, “Fire Sales in a Model of Complexity,” Journal of Finance 68 (December 2013), pp. 2549-87.

Calomiris, Charles A. and Eugene N. White, "The Origins of Federal Deposit Insurance," in Claudia Goldin and Gary D. Libecap, The Regulated Economy: A Historical Approach to Political Economy (Chicago: University of Chicago Press, 1994), pp. 145-188.

Carlson, Mark, Kris James Mitchener and Gary Richardson, Arresting Banking Panics: Fed Liquidity Provision and the Forgotten Panic of 1929," Journal of Political Economy 119:5 (October 2011), pp. 889-924.

Chandler, Lester V., Benjamin Strong, Central Banker (Washington, D.C.: Brookings Institution, 1958).

Diamond, Douglas W. and Raghuram G. Rajan, "Fear of Fire Sales, Illiquidity Seeking and Credit Freezes," Quarterly Journal of Economics (2011) 126:2, pp. 557-591.

Eichengreen, Barry, Arnaud J. Mehl, Livia Chitu, and Gary Richardson, "Mutual Assistance between Federal Reserve Banks, 1913-1960.,” NBER Working Paper 20267 (June 2014).

Federal Reserve Act, An Act To provide for the establishment of Federal reserve banks, to furnish an elastic currency, to afford means of rediscounting commercial paper, to establish a more effective supervision of banking in the United States, and for other purposes," (December 23, 1913), The Statues at Large of the United States Vol. XXXVIII, (Washington, D.C., 1915).

Federal Reserve Bank of Atlanta, Annual Reports (Atlanta, 1919, 1920, 1921).

Federal Reserve Bank of Atlanta, Office of the Secretary, Board of Directors, minutes.

Federal Reserve Bank of Atlanta, Office of the Secretary, Executive Committee of the Board of Directors, minutes. 
Federal Reserve Bank of Atlanta, Library, daily consolidated balance sheets.

Federal Reserve Board, Annual Reports (Washington, D.C., 1919, 1920, 1921, 1922).

Freixas, Xavier and Bruno M. Parigi, "Lender of Last Resort and Bank Closure Policy," in Allan N. Berger, Philip Molyneux, and John O.S. Wilson, The Oxford Handbook of Banking $2^{\text {nd }}$ Ed. (Oxford: Oxford Univeristy Press, 2014), pp. 475-504.

Freixas, Xavier and Bruno M. Parigi and Jean-Charles Rochet, "Systemic Risk, Interbank Relations and Liquidity Provision by the Central Bank," Journal of Money, Credit and Banking 32:2 (2000), pp. 611-638.

Friedman, Milton and Anna J. Schwartz, A Monetary History of the United States 18??-1960 (Princeton: Princeton University Press, 1963).

Gamble, Richard H., A History of the Federal Reserve Bank of Atlanta, 1914-1989 (Federal Reserve Bank of Atlanta, 1989).

Garrett, Franklin, "History of the Federal Reserve Bank of Atlanta" Archives of the Federal Reserve Bank of Atlanta, unpublished.

Harding, W.P.G., The Formative Period fo the Federal Reserve System (London: Constable and Company Ltd., 1925).

Hautcoeur, Pierre.-Cyrille, Angelo Riva, and Eugene N. White, "Floating a Lifeboat: the Banque de France and the Crisis of 1889," Journal of Monetary Economics 65 (July 2014), 104-119.

Joint Commission of Agricultural Inquiry, Hearings Before the, (Sixty-Seventh Cong. $1^{\text {st }}$. Sess.) 3 Vols. (Washington D.C.: Government Printing Office, July, August and November 1921).

Meltzer, Allan H., A History of the Federal Reserve Vol. I, 1913-1951, (Chicago: University of Chicago Press, 2003).

Mishkin, Frederic S. and Eugene N. White, "Unprecedented Actions: The Federal Reserve's Response to the Global Financial Crisis in Historical Perspective," NBER Working Paper No. 20737 (December 2014)

National Bureau of Economic Research, U.S. Business Cycle Expansions and Contractions. http://nber.org/cycles/cyclesmain.html

National Bureau of Economic Research, Macro History IV. Prices. New York Wholesale Price of Cotton, 1870-1945 (2008).

http://www.nber.org/databases/macrohistory/contents/chapter04.html

Measuring Worth, Consumer Price Index, (2014) http://www.measuringworth.com/uscpi/ 
Moen, Jon and Ellis W. Tallman, "The Bank Panic of 1907: The Role of the Trust Companies," Journal of Economic History 52:3 (September 1992), pp. 661-630.

Richardson, Gary and William Troost, "Monetary Intervention Mitigated Banking Panics during the Great Depression: Quasi-Experimental Evidence from a Federal Reserve District Border, 1929-1933," Journal of Political Economy 117: 6 (2009), pp. 1031-73.

Shleifer, Andrei and Robert W. Vishny, "Asset Fire Sales and Credit Easing," American Economic Review 100:2, pp. 46-50.

Shleifer, Andrei and Robert W. Vishny, "Fire Sales in Finance and Macroeconomics," Journal of Economic Perspectives 25(1), pp. 29-40.

White, Eugene N., "To Establish a More Effective Supervision of Banking: How the Birth of the Fed Altered Bank Supervision," in M.D. Bordo and W. Roberds, The Origins, History and Future of the Federal Reserve: A Return to Jekyll Island (Cambridge: Cambridge University Press, 2013), pp. 7-54. 